\title{
Black education in South Africa: issues, problems and perspectives
}

\section{Alex Thembela}

In this article Professor Thembela, Vice-Chairman of the Board of Trustees, UPTTRAIL Trust*, sketches some of the issues which constitute major problems in the education of black South Africans. In the first place the discontinuity between the pupils' traditional home background and a Westernized system of education creates severe obstacles. They are aggravated by the fact that black culture is itself in transition, by the contempt with which black culture was regarded by the colonialists and by the discriminatory political practices which denied black education adequate provision.

Other issues that further complicate black education are:

* the second language medium of instruction which has been adopted for the purpose of securing international participation but which doubles the burden on the black learner and contributes to an appalling failure rate

* the inadequate qualifications of black teachers

* inadequate financing of black education

* the impoverished communities from which black pupils and teachers come

* the perception among many black pupils that their education is inferior

* the situation of cultural, social and political conflict created by the development of black education.

To remedy such a situation, intervention of an exceptional nature is needed. The UPTTRAIL project promises to provide such intervention.

In hierdie artikel skets Professor Thembela, Vise-voorsitter van die Raad van Trustees, UPTTRAIL Trust, van die hoofprobleme in die swart onderwys in Suid-Afrika. In die eerste plek veroorsaak die gaping tussen die leerlinge se tradisionele huislike agtergrond en 'n verwesterse onderwysstelsel geweldige probleme. Dit word vererger deur die oorgangsfase waarin die swart kultuur homself bevind, deur die minagting waarmee die swart kultuur deur die kolonialiste beskou is en deur die diskriminerende politieke wanpraktyke wat die swart onderwys baie ontsê het.

* The educational Trust responsible for launching the UPTTRAIL pilot project. 
Ander sake wat swart onderwys verder kompliseer, is

* die gebruik van die tweede taal as onderrigmedium wat aanvaar is om internasionale deelname te verseker, maar wat die las op die swart leerling verdubbel het en bygedra het tot 'n geweldige druipsyfer

* die onvoldoende kwalifikasies van swart onderwysers

* onvoldoende fondse vir swart onderwys

* die verarmde gemeenskappe waaruit swart leerlinge en onderwysers kom

* die persepsie onder baie swart leerlinge dat hul onderwys minderwaardig is

* die kulturele, sosiale en politieke konflik wat deur die ontwikkeling van swart onderwys geskep is.

Om hierdie probleemop te los is ingryping van buitengewone aard nodig. Die UPTTRAILprojek het dié soort ingryping ten doel.

\section{Introduction}

In this article I am going to discuss some issues which constitute major problems in the education of black South Africans. In order to fit these issues into their context, it will be necessary to start with a brief historical sketch and also to mention some socio-political issues. It is in this context that the particular issues relating to education can be properly understood and appreciated. My thesis in this article is that the problems in the education for black South Africans emanate from a complex set of influences and anyone who desires to contribute something towards the amelioration or elimination of these problems must enter the arena at certain strategic points.

\section{Brief historical background}

School education for black South Africans was grafted on the social and cultural life of the various tribal societies by the missionaries towards the end of the 18th century, but particularly in the middle of the 19th century. The intention in this discussion is not to sketch the history of the introduction of formal school education amongst the South African blacks. The issue that is being highlighted here is that the introduction of school education divided blacks not only into educated and non-educated classes, but also into christianised and nonchristianised groups. When industrialisation and urbanisation later took place, both groups were affected, for these social processes set in motion a dynamic movement away from the stable norm of traditionalism to the highly unstable conditions of modernism.

Those groups or individuals who have been favoured by circumstances, and who have also possessed the ability to adapt quickly to new conditions, have moved faster through the process of social transformation. Those left behind at various stages of development have been resident mainly in the rural areas. This process has been complicated by the South African political system that has discriminated against blacks in the matter of providing facilities. 
It is necessary to understand that during the Missionary era (up to 1953), Christian norms were clearly and deliberately pursued. School education was mainly in aid of evangelising the blacks. Schools in the mission stations drew pupils from families that accepted Christianity. When mass education was promoted for a quarter of a century during the Bantu Education era (1954-1979), pupils emerged from families which were at various stages of transition from traditionalism to modernism. The heterogeneous social background of the pupils made it difficult for teachers to uphold a consistent value system. The teachers themselves did not understand the educational implications of these social dynamics because of their own background and low qualifications. As a consequence, school education became concerned merely with the imparting of the bare facts of the subject matter, which were hardly related to the daily lives of the pupils.

This phenomenon of cultural discontinuity between the pupils' home background and school education has been found in many countries in Africa. Shehu $(1984$, p.31) reports that the agents of colonialism, whether civil servants, members of armed forces, missionaries, explorers or traders, ridiculed, criticised and often humiliated Africans regarding their cultural heritage. African religions were labelled primitive, works of art were described as crude and immoral, dances were seen as ritualistic and sensual. None of these age-old heritages was considered worthy of any respect or preservation. Western European standards were applied to Africa and pursued vigorously with the effect that the African increasingly admired Western culture. What we are saying here is that whereas school education was part of the culture of Europe, there was cultural discontinuity in Africa which created an obstacle to African advancement. African education must find a way of introducing modern technology quickly and effectively so that indigenous populations can assimilate this technology in such a way as to have full command of it.

\section{Wider issues}

One issue that we need to highlight at a socio-political level is the one of social norms. School education usually promotes middle class norms. Pupils from the lower classes or disadvantaged groups have always found it difficult to compete with pupils who come from middle class homes. In South Africa, black people not only come from a culture in transition, but they are also at the bottom of the South African social structure which happens to be determined by race as well. Nevertheless, a sizeable number have been able to surmount the social and cultural barriers and are able to compete favourably with the other race groups (but they are exceptions). The core of the problem is that there is a great majority of black people who are, educationally, seriously handicapped and cannot get out of this dilemma. Something quite drastic must be done to address this problem.

This problem is complicated by the political issues which have created an evironment of discrimination agains blacks and made it difficult for them to overcome their educational problems. If blacks merely had to handle the problem of coping with a situation of adapting a foreign system of education to their social and cultural circumstances (without having to be bothered by the political struggle), they would have sufficient homework to do.

The discriminatory practices in the provision of education for blacks have created a perception in them which has filtered down to the pupils that they are being educated for slavery. Black students and pupils have been boycotting classes and even burning down 
their own schools. This may seem to be a futile, stupid and self-defeating exercise, but it is a rejection of a system that has lost its credibility.

This is the dilemma in which black education finds itself today. The Department of Education and Training (of the white government) has increased its budget dramatically since 1976 and much improvement and many innovations have been effected, but perceptions of "education for slavery" still persist in some quarters. In this case the social arrangements in the country, born out of the prevailing political system, are a main cause of dissatisfaction and constitute an obstacle to educational advancement for black South Africans.

These cultural and socio-political issues constitute the wider context within which the following specific issues can be viewed.

\section{Specific issues}

\section{The language issue}

Several threads complicate this issue. Viewed from historical perspectives, there is first a colonial hangover and indoctrination that make some black people believe that a really educated person is the one who speaks English very well. Then there is the apparent contradiction between the desire for the development of national and cultural pride on the one hand and the desire for westernisation on the other. This policy is manifested in the language policy of the schools. A very strong argument for the use of English as the medium of instruction in black schools in South Africa is that English is an international language, a language of commerce and industry, of science and literature. On the other hand, it is argued that while the use of the African languages as media of instruction would be pedagogically sound, the use of these languages, it is asserted, would lock the blacks into their small tribal cultural kraals from which they would not emerge. Black children, therefore, learn through their various mother tongues for the first four years and thereafter switch over to English as a medium of instruction. Black pupils, particularly from rural areas seldom hear or use English outside the classroom. Obviously, the use of a foreign medium presents the child with the double problem of having to struggle with the language as well as with the concepts of a particular subject. It must also be pointed out that the subject matter is itself western-oriented, selected and ordered from Western culture. Black pupils leam more about the French and American revolutions, and very little about the African struggles for independence. Many blacks learn about electricity when there is none in their environment.

The extent to which the use of a foreign language as medium of instruction affects the cognitive development of black pupils has not been properly investigated. It seems that the great majority of pupils struggle along and give up sooner or later. This may be one reason amongst others for the great drop-out rate among black pupils. Add to this difficult situation the fact that many black teachers themselves have not properly mastered either the language of instruction or the concepts they are transmitting.

\section{Teachers' qualification}

The present norm for an acceptably qualified teacher in South Africa is Grade 12 (Standard 10) plus a three years' professional qualification. In 1983 only $23,1 \%$ of teachers in black schools were properly qualified. In this regard a Report of the Human Sciences 
Research Council (1981) said "Without a corps of well-trained and talented teachers, any endeavour aimed at a system of education by means of which the potential of the country's inhabitants is to be realised, economic growth promoted, the quality of life of the inhabitants improved and education of quality provided for everyone, cannot be successful."

\section{Pupil-teacher ratio}

The pupil teacher ratio for 1983 was as follows for the different racial groups:

\begin{tabular}{llll}
\hline WHITES & ASIANS & COLOUREDS & BLACKS \\
$18,2: 1$ & $23,6: 1$ & $26,7: 1$ & $42,7: 1$ \\
\hline
\end{tabular}

Source: Survey of Race Relations in South Africa 1983, Johannesburg, for 1984 p. 421.

Financing of education

Despite the fact that a considerable amount of money has been made available by the government for black education since 1976, the gap that still exists between the amounts spent on the black child and children of other race groups remains unacceptably wide as the following table indicates:

\section{PER CAPITA EXPENDITURE ON EDUCATION 1982/83:}

INCLUDING EXCLUDING
CAPITAL EXPENDITURE

WHITE

COLOUREDS

INDIAN

BLACK
R 1385,00

871,87

591,37

192,34
R1 211,00

711,16

497,59

146,44

Source: Survey of Race Relations in South Africa, 1983, p. 420

The situation is changing now as the government begins to put in more money into black education.

The consequences of the socio-political environment described above, the poor qualifications of teachers, inadequate financing and a low teacher-pupil ratio show themselves in the following symptoms:

(a) Drop out rate

STANDARD

OR GRADE

2 (Gr. 4)

5 (Gr. 7 )

8 (Gr. 10)

10 (Gr. 12)
ORIGINAL ENROLMENT

687990

624942

515449

443030
STILL AT SCHOOL IN 1975

NUMBER PERCENTAGE

$\begin{array}{rr}419212 & 60,9 \\ 221019 & 35,4 \\ 50772 & 9,9 \\ 9009 & 2,0\end{array}$

Source: Energos, 1983, p. 56

Many black children are leaving school without obtaining sustainable literacy. If this situation does not change, there will continue to be an increasing number of uneducated and under-educated people in South Africa. 
(b) Failure rate

Even for those pupils who survive the high drop-out rate and reach standard 10 (Grade 12) there has been an increasing rate of failure as the number of candidates increased.

BLACK MATRICULANTS - 1979-1983

\begin{tabular}{lrrrrr}
\hline YEAR & $\begin{array}{r}\text { NO. OF } \\
\text { CANDIDATES }\end{array}$ & $\begin{array}{r}\text { NO. } \\
\text { PASSED }\end{array}$ & $\%$ & $\begin{array}{r}\text { NO. } \\
\text { OBTAINING } \\
\text { MATRIC }\end{array}$ & $\%$ \\
& & & & 4136 & 28,5 \\
EXEMPTION & \\
\hline 1979 & 14574 & 10706 & 73,5 & 4714 & 15,7 \\
1980 & 29973 & 15935 & 53,2 & 6069 & 12,5 \\
1981 & 48571 & 25963 & 53,5 & 6336 & 10,5 \\
1982 & 60108 & 30541 & 50,8 & 7108 & 9,8 \\
1983 & 72168 & 34876 & 48,3 & & \\
\hline
\end{tabular}

Source: Survey of Race Relations in South Africa, 1983, p. 439

There are indications of improvement in the pass rate since 1987.

\section{Conclusion}

The perspective I wish to emphasize is that since educational disability is usually found among socially and economically disadvantaged groups in all societies, we can conclude that there is a systematic relationship between social conditions and educational competence. The culturally deprived child may also be retarded in cognitive skills by the time he enters school. Many black children come from squalid slums on the periphery of large cities, which, with their overcrowded apartments offer a limited range of stimulation to a child. Little money is available for newspapers, books, magazines, and few black communities or schools possess libraries. Any attempt to improve the quality and qualifications of teachers is frustrated by these many handicaps. The nett effect is that schools are not producing properly educated individuals who can hold their own anywhere in the world of science and art, literature and religion, commerce and industry (in sufficient numbers). Instead, schools are providing a powder keg of resistance as more and more pupils perceive the conditions at school to be an inevitable consequence of the general socio-political situation in the country.

In summary, in this paper I have tried to show that the historical development of school education for blacks in South Africa created a situation of cultural and social conflict that made it difficult for education to proceed smoothly. The South African socio-political arrangements place blacks at the bottom of the social structure, thus creating tremendous obstacles for blacks and making it difficult for them to do well at school. The conditions which exist in black schools make it difficult to attain effective transmission of knowledge, proper development of skills and the acquisition of understanding and insight by pupils. The absence of a supportive environment in homes and schools within which wholesome attitudes and appreciation may develop, and the absence of means and the lack of capacity by teachers to develop in their pupils qualities of creativity, reasoning powers and originality, all add up to a situation posing serious obstacles to advancement in black 
education. It has always been a source of amazement that many blacks still achieve educational eminence in spite of these problems.

The purpose of this article was not to provide answers to the many problems that beset the education for blacks in South Africa. This situation calls for wider and deeper attention to the transformation of South African society and at the same time special and deliberate attention to all those specific issues that constitute obstacles to the realisation of educational goals. It seems to me the development of language and thinking skills that the UPTTRAIL Trust tries to attend to goes to the heart of the matter in an attempt to solve the problem.

\section{References}

ANNUAL Report. 1983. Department of Education and Training, Pretoria.

ENERGOS. 1983. Published for Mobil Oil S.A. (Pty) Ltd. by Aviation Publications, Johannesburg.

HUMAN Sciences Research Council. 1981. Provision of education in the R.S.A., Pretoria. KALLAWAY, P. (Ed.). 1984. Apartheid and education: The Education of black South Africans. Johannesburg: Ravan Press.

SURVEY of race relations in South Africa. 1983. Johannesburg: South African Institute of Race Relations, 1984.

SHEHU, U. 1984. The African predicament, culture, identity, science and technology in the 20th century. In Africa: Review of German-African relations. Vol XXV No. 1.

THEMBELA, A.J. 1986. Educational obstacles to black advancement. In Smollen R. (Ed.), Black advancement in the South African economy. MacMillan South Africa (Publishers) Pty Ltd, Braamfontein, Johannesburg. 